\title{
Academic Hardiness dan Prokrastinasi pada Mahasiswa
}

\author{
Muharrama Trifiriani, Ivan Muhammad Agung
}

Fakultas Psikologi Universitas Islam Negeri Sultan Syarif Kasim Riau email: ivan.agung@uin-suska.ac.id

\begin{abstract}
Abstrak
Prokrastinasi merupakan salah satu masalah yang dihadapi mahasiswa dalam menyelesaikan tugasnya.. Penelitian bertujuan untuk mengetahui hubungan antara academic hardiness dengan prokrastinasi pada mahasiswa. Pengumpulan data dilakukan dengan skala academic hardiness dan skala prokrastinasi. Subjek penelitian berjumlah 301 mahasiswa/i. Analisa data dilakukan menggunakan product moment correlation oleh pearson. Hasil penelitian ini, menunjukkan koefisien korelasi $(r)$ sebesar $-0,177$ dengan probabilitas ( $p$ ) $0,001(p \leq 0,01)$. Hasil analisis data menunjukkan bahwa ada hubungan negatif antara academic hardiness dengan prokrastinasi pada mahasiswa/i. Artinya, semakin tinggi academic hardiness maka semakin rendah prokrastinasi. Selain itu, hasil penelitian menunjukkan sumbangan efektif academic hardiness terhadap prokrastinasi sebesar 3,1\%.
\end{abstract}

Kata kunci: academic hardiness, prokrastinasi, mahasiswa

\section{Academic Hardiness and Procrastination on Undergarduate
Student}

\begin{abstract}
Procrastination is one of the problems faced by students in completing their duties. The research aims to find out the relationship between academic hardiness and procrastination to the students. The data was collected by academic hardiness and procrastination scale. Research subjects amounted to 301 undergraduate students. Data analysis was done using product moment correlation by Pearson. The results of this study, showed the correlation coefficient $(r)$ of -0.177 with probability $(p) 0.001(p \leq 0.01)$. The result of data analysis shows that there is a negative correlation between academic hardiness and procrastination on student. That is mean, the higher the academic hardiness, the lower the procrastination.In addition, the results showed an effective contribution of academic hardiness to procrastination of $3.1 \%$.
\end{abstract}

Keywords: academic hardiness and procrastination, undergarduate student

\section{Pendahuluan}

Mahasiswa dipersiapkan menjadi sumber daya manusia yang mampu menghadapi persaingan global, sehingga sampai saat ini mahasiswa masih menjadi tumpuan dan harapan bangsa. Mahasiswa yang sedang menempuh pendidikan di perguruan tinggi dituntut untuk menyelesaikan studinya dalam jangka waktu yang telah ditentukan. Tuntutan tersebut dapat berasal dari orangtua yang ingin segera melihat anaknya memperoleh gelar yang dapat dibanggakan, tuntutan institusi akademik, tuntutan biaya dari perguruan tinggi, teman-teman, dosen, maupun keinginan dari diri sendiri (Andarini \& Fatma, 2013). Masalah yang dihadapi oleh mahasiswa tidak hanya berkaitan dengan permasalahan-permasalahan individu dengan orang lain, na- mun bisa juga terjadi terhadap tugasnya itu sendiri terutama perilaku menunda terhadap tugas, atau biasa disebut prokrastinasi. Senecal, dan Koestner, (1995).mengemukakan bahwa prokrastinasi adalah saat seseorang seharusnya melakukan suatu kegiatan dan bahkan mungkin ingin melakukannya, namun gagal memotivasi diri untuk melakukan aktivitas tersebut dalam jangka waktu yang diinginkan atau diharapkan. Menurut Salomon dan Rhotlum (1984) bahwa prokrastinasi merupakan perilaku menunda tugas akademik secara sengaja. Maka dari itu, dapat disimpulkan bahwa prokrastinasi adalah perilaku menunda yang dilakukan secara sengaja, hingga melewati batas waktu yang telah ditentukan.

Ferrari, dkk (1995) mengatakan bahwa prokrastinasi akademik dapat termanifestasikan dalam indikator tertentu yang dapat 
diukur dan diamati ciri-ciri tertentu berupa:1) penundaan untuk memulai dan menyelesaikan tugas, 2) keterlambatan dalam mengerjakan tugas,3) kesenjangan waktu antara rencana dan kinerja aktual, dan 4) melakukan aktivitas yang lebih menyenangkan. Menurut Sitat (dalam Steel, 2007) prokrastinasi pada mahasiswa menunjukkan frekuensi tertinggi dibandingkan prokrastinasi pada hal lainnya. Hasil penelitian yang dilakukan oleh Solomon dan Rothblum (1984), dilaporkan bahwa paling banyak mahasiswa melakukan prokrastinasi ketika menulis lembar tugas, dengan persentase sebanyak $46 \%$, sedangkan $30 \%$ ketika membaca tugas mingguan, $28 \%$ ketika belajar untuk ujian, 23\% ketika menghadiri kelas, dan $11 \%$ pada tugas-tugas administratif. Selain itu, di dalam negeri yaitu Sari (dalam Julianda, 2012) mengatakan bahwa mahasiswa yang melakukan prokrastinasi tergolong tinggi sekitar 37,6\% dari 231 mahasiswa Fakultas Psikologi Universitas Surabaya. Hal senada juga berdasarkan studi awal oleh Kartadinata dan Tjundjing (2008) pada 60 mahaisiswa yang menunjukkan sekitar 95\% mengatakan bahwa mereka pernah melakukan prokrastinasi. Dua alasan terbesar yang membuat mereka melakukan prokrastinasi adalah rasa malas mengerjakan tugas $(42 \%)$ dan banyak tugas lain yang harus dilakukan $(25 \%)$.

Perilaku prokrastinasi akademik yang dilakukan oleh para mahasiswa terdapat dampak yang negatif secara internal maupun eksternal. Adapun dampak internal dari prokrastinasi akademik antara lain merasa bersalah atau menyesal, waktu yang terbuang sia-sia, stres yang meningkat, penurunan kesehatan, kepercayaan diri yang rendah, tingginya tingkat membolos, putus sekolah, sedangkan dampak eksternal dari prokrastinasi akademik yaitu tugas tidak terselesaikan dengan baik, rendahnya baik nilai maupun prestasi belajar, dan mendapat peringatan dari guru (Burka \& Yuen, 2008).

Banyak faktor yang mempengaruhi prokrastinasi akademik baik dari internal (kepribadian) dan eksternal (lingkungan). Beberapa penelitian prokrastinasi akademik dikaitkan self efikasi (Julianda,2012), perfek- sionisme (Gunawinata, \& Lasmono, 2008; Ananda, \& Mastuti, 2013), religious dan hardiness (Nasab \& Aria, 2015). kontrol diri (Nela, \& Nadia, 2013; Ursia, Saputra, \& Sutanto, 2013), motivasi berprestasi (Rumiani. (2006), distress dan dukungan sosial (Sekar \& Anne (2013), regulasi diri (Senecal, \& Koestner 1995); dan manajemen waktu (Kartadinata dan Tjundjing, 2008) Dalam penelitian ini peneliti fokus pada faktor internal khusunya kepribadian hardiness. Salah satu alasannya adalah belum banyak penelitian terutama yang mengkaitkan akademik hardiness dengan prokrastinasi pada konteks Indonesia.

Hardiness biasa disebut dengan kepribadian tahan banting. Hardiness adalah kombinasi dari sikap yang memberi keberanian dan motivasi untuk melakukan kerja keras atau kegiatan untuk dapat bertahan dalam suatu masalah yang menimbulkan stres (Maddi, 2006). Menurut Kobasa (dalam Hystad 2012), hardiness merupakan susunan karakteristik kepribadian yang berfungsi sebagai sumber daya pantul dalam menghalangi stres dalam kehidupan. Kobasa, dkk (dalam Nazmiye \& Asım, 2015) hardiness didefinisikan sebagai ciri kepribadian yang menahan efek negatif dari stres. Menurut Benishek dan Lopez (2001) dan Benishek dkk., (2005) hardiness akademik mengacu pada ketahanan seseorang untuk bertahan dalam akademik. Seseorang dengan hardiness menampilkan kesediaan untuk terlibat dalam karya akademis yang menantang, berkomitmen untuk kegiatan akademik, dan menganggap mereka memiliki kontrol atas kinerja dan hasil. Menurut Benishek dan Lopez (2001) akademik hardiness mengacu pada dua teori kognitif berorientasi yaitu teori Kobasa tentang hardiness dan teori Dweck tentang motivasi akademik, yang berguna dalam memahami mengapa beberapa siswa bertahan ketika menghadapi kesulitan akademik sedangkan yang lainnya tidak.

Kedua teori tersebut saling komplementer memberikan kerangka untuk memahami bagaimana mahasiswa dapat bereaksi terhadap tantangan akademis. mahasiswa yang memandang diri mereka memiliki kemampuan untuk mencapai tujuan akademik 
melalui pengaturan diri usaha dan emosional (kontrol), yang bersedia untuk melakukan pengorbanan pribadi untuk unggul secara akademis (komitmen), dan yang sengaja mencari pekerjaan sulit tertentu karena melakukannya dapat memberikan pertumbuhan pribadi jangka panjang (tantangan) mungkin lebih cenderung untuk berjalan dari orientasi berbasis pembelajaran daripada orientasi berbasis prestasi. Konseptualisasi ini membimbing pengembangan versi awal dari Skala Academic Hardiness (AHS) (Benishek \& Lopez, 2001).

Menurut teori Kobasa (dalam HudekKnezevic dan Krapic,2012) Hardiness terdiri dari tiga buah aspek yaitu :a) Control (kontrol), yaitu kecenderungan untuk meyakini bahwa dirinya mampu mempengaruhi bermacammacam peristiwa yang tidak menentu dalam hidupnya. , 2) Commitment (Komitmen), yaitu merupakan sebuah kecendrungan untuk melibatkan diri kedalam situasi yang sedang dilakukan atau dihadapi. Kardum, HudekKnezevic, dan Krapic (2012), mendefinisikan komitmen sebagai tendensi untuk melibatkan diri dalam sebuah aktifitas dalam hidup, memiliki minat yang sungguh-sungguh, serta keingintahuan yang kuat mengenai aktifitas tersebut.,dan 3) Challange (tantangan) merupakan kecenderungan untuk meyakini bahwa perubahan-perubahan yang terjadi dalam hidup adalah sesuatu yang wajar dalam sebuah kehidupan.

Mahasiswa yang dapat bertahan dalam kondisi stres dan penuh tekanan dapat dikategorikan sebagai mahasiswa yang memiliki aspek-aspek didalam kepribadian akademik hardiness karena mereka memiliki kontrol terhadap masalah yang dihadapi, komitmen untuk tetap terlibat dalam pengerjaan tugas, juga memilki anggapan bahwa sebuah masalah yang dialami sebagai sebuah tantangan bukanlah ancaman.Menurut penelitian yang dilakukan oleh Nasab dan Aria (2015) hardiness psikologis berhubungan dengan prokrastinasi akademik. Hasil penelitian tersebut menunjukkan bahwa individu memiliki academic hardiness tinggi akan mengurangi perilaku prokrastinasi akdemik.
Berdasarkan kerangka yang dipaparkan, maka hipotesis yang diajukan pada penelitian ini yaitu ada hubungan negatif antara hardiness akademik dengan prokrastinasi.

\section{Metode}

\section{Subjek}

Jumlah subjek dalam penelitian ini adalah 301 mahasiswa psikologi UIN Suska Riau. Karakteristik subjek penelitiannya adalah mahasiswa/i semester 7 berjumlah 98 orang sebesar $32,56 \%$, semester 5 berjumlah 86 orang sebesar $28,58 \%$, semester 9 berjumlah 60 orang sebesar $19,93 \%$, semester 3 berjumlah 34 orang sebesar $11,29 \%$, semester 1 berjumlah 18 orang sebesar $5,98 \%$, semester 11 sejumlah 5 orang sebesar 1,66\%.

\section{Pengukuran}

Alat ukur untuk yang digunakan untuk dalam penelitian adalah skala prokrastinasi dan skala academic hardiness. skala prokrastinasi disusun mengacu pada ciri-ciri prokrastinasi oleh Ferrari dkk (1995). Skala academic hardiness yang dibuat berdasarkan terjemahan dan modifikasi alat ukur RAHS (Revised Academic Hardiness Scale) (Benishek, dkk., 2005). Aitem-aitem disusun mengacu kepada tiga aspek academic hardiness yaitu kontrol, sebanyak komitmen, dan tantangan. Skala disusun berdasarkan modifikasi skala Likert yang disusun dengan empat alternatif jawaban, yaitu yang diberikan berada pada rentang dari 1 (satu) sampai 4 (empat),

Sebelum penelitian dilaksanakan, maka alat ukur yang akan digunakan harus di uji cobakan terlebih dahulu. Uji coba diberikan kepada 60 orang mahasiswa fakultas pertanian dan peternakan UIN sulthan syarif kasim Dari 31 item skala academich hardiness terdapat 29 aitem yang valid dan 2 item yang gugur. Semenetara untuk skala prokrastinasi dari jumlah item tersebut terdapat 32 item yang valid. Sedangkan item yang dinyatakan gugur atau tidak valid adalah 3 item. Uji coba alat ukur (try out) dilakukan untuk mengetahui tingkat validitas dan reliabilitas guna mendapat aitem yang layak sebagai alat ukur. Koefisien reliabilitas untuk skala academic 
hardiness yaitu 0,954 dan pada skala prokrastinasi memiliki koefisien reliabilitas 0,940

\section{Analisis Data}

Data kuesioner yang telah dikumpulkan akan diolah untuk menguji hipotesis dengan menggunakan analisis data korelasi Product Moment Pearson yang digunakan untuk mengetahui besarnya hubungan antara variabel $X$ (academic hardiness) dengan variabel Y (prokrastinasi).

\section{Hasil}

\section{Uji hipotesis}

Berdasarkan hasil analisis diperoleh nilai koefisien korelasi antara academic hardiness $(X)$ dengan prokrastinasi pada mahasiswa $(Y)$ adalah $r=-0,177$ pada taraf signifikansi, $p=0,001(p \leq 0,01)$. Adapun ketentuan diterima atau ditolak sebuah hipotesis apabila signifikansi di bawah atau sama dengan 0,05 $(p \leq 0,05)$ maka hipotesis diterima (Sugiyono, 2013). Dalam hal ini probabilitas (p) yaitu, 0,001 lebih kecil dari pada $0,05(0,000 \leq 0,01)$. Jadi hipotesis terdapat hubungan negatif antara academic hardiness dengan prokrastinasi pada mahasiswa diterima. Artinya semakin tinggi academic hardiness maka semakin rendah prokrastinasi pada mahasiswa. Nilai Rsq sebesar 0,031 Artinya, sumbangsih academic hardiness terhadap prokrastinasi pada mahasiswa adalah sebesar $3,1 \%$.

\section{Pembahasan}

Tujuan dari penelitian ini adalah untuk mengetahui apakah ada hubungan negatif antara academic hardiness dengan prokrastinasi pada mahasiswa. Berdasarkan hasil analisis data menunjukkan bahwa terdapat hubungan antara academic hardiness dengan prokrastinasi pada mahasiswa dengan nilai signifikansi 0,001 ( $p \leq 0,01)$. Berdasarkan hasil analisis diperoleh koefisien korelasi $(r)$ yaitu sebesar $-0,177$. Tanda negatif (-) di depan angka koefisien korelasi menunjukkan adanya hubungan yang negatif atau arah hubungan dengan arah negatif, yang berarti bahwa kenaikan suatu variabel berbanding terbalik dengan variabel lain. Dengan kata lain, semakin tinggi academic hardiness seseorang maka semakin rendah prokrastinasinya, sebaliknya semakin rendah akademik hardiness seseorang maka semakin tinggi prokrastinasinya. Nilai koefisien $-0,177$ berada pada tingkat yang sangat rendah karena hasil penelitian ini hanya memberikan sumbangan efektif sebesar 3,1\% sedangkan sisanya ditentukan oleh faktor lain.

Hail penelitian ini didukung penelitian Vinothkumar dkk., (2016); dan Etemadi \& Feily (2016) yang menyatakan bahwa academic hardiness memiliki hubungan negatif dengan kinerja akademik dan prokrastinasi. Para peneliti telah menemukan salah satu alasan terjadi prokrastinasi adalah ketidakmampuan seseorang dalam menghadapi tugas dan tantangan yang tidak bisa diselesaikan. Menurut Nakamura dan Csikszentmihalyi (dalam Vinothkumar, Kousalya, Vindya. 2016) bahwa ketika keterampilan seseorang lebih tinggi dari tantangan yang merupakan salah satu faktor academic hardiness, bisa menyebabkan kebosanan yang merupakan faktor lain yang menyebabkan terjadinya prokrastinasi.

Schultz dan Schultz (dalam Nurtjahjanti, H \& Ratnaningsih, 2011) menjelaskan bahwa individu yang memiliki tingkat hardiness yang tinggi memiliki sikap yang membuat mereka lebih mampu dalam melawan stres. Individu yang memiliki academic hardiness yang rendah dalam kondisi memiliki ketidakyakinan akan kemampuan dalam mengendalikan situasi. Individu dengan hardiness yang rendah memandang kemampuannya rendah dan tidak berdaya serta diatur oleh nasib. Penilaian tersebut menyebabkan kurangnya pengharapan, membatasi usaha dan mudah menyerah ketika mengalami kesulitan sehingga mengakibatkan kegagalan.

Academic hardiness memiliki peran dalam terjadinya perilaku prokrastinasi pada mahasiswa. Hal ini sesuai dengan pernyataan yang dijelaskan, bahwa academic hardiness dalam diri seseorang memiliki pengaruh terhadap prokrastinasi, karena aspek yang ada di dalam academic hardiness (kontrol, komitmen, dan tantangan) merupakan karak- 
orang yang penting dalam mengurangi perilaku prokrastinasi kademik.pertama, kontril. Individu yang memiliki kemampuan untuk mengontrol perilaku dan lebih mendahulukan yang penting cenderung memiliki prokrastinasi rendah. Hal tersebut didukung penelitian Endrianto (2014) dan Ursia dkk (2013) menunjukkan bahwa individu yang memiliki kontrol diri tinggi cenderung memilki prokrastinasi rendah.

Kedua, komitmen. Individu yang memiliki komitmen akan berusaha melaksanakan tugas yang diberikan degan baik dan tepat waktu. Ketiga, tantangan, Kardum, dkk (2012) mengatakan tantangan sebagai keyakinan bahwa perubahan dalam hidup dapat menjadi sesuatu yang menguntungkan bagi perkembangan diri sendiri. Individu yang memiliki tantangan cenderung percaya diri dan yakin akan kemampuan dalam menyelesaikan tugas. Hasil penelitian Julianda (2012) menunjukkan bahwa individu yang yang memiliki efikasi diri tinggi (yakin akan keberhasilan tugas) maka cenderung tidak melakukan prokrastinasi akademik.

Dalam penelitian ini ditemukan bahwa sumbangan yang diberikan oleh variabel academic hardiness terhadap prokrastinasi relative kecil yaitu sebesar $3,1 \%$. Hal ini menunjukkan sekitar $96,9 \%$ yang diberikan oleh variabel lain terhadap prokrastinasi pada mahasiswa. Beberapa variabel lain yang dapat memberikan sumbangan terjadinya perilaku prokrastinasi yaitu stress, manajemen waktu, karakter tugas dan religiusitas.

\section{Kesimpulan}

Berdasarkan hasil penelitian dan pembahasan dapat disimpulkan bahwa terdapat hubungan negatif antara akademik hardiness dengan prokrastinasi pada mahasiswa. Semakin tinggi academic hardiness maka semakin rendah prokrastinasi pada mahasiswa. Kekuatan hubungan antara akademik hardiness dengan prokrastinasi dikategorikan rendah. Oleh karena itu, perlunya mengkaji factor-faktor lain yang lebih berperan dalam prokrastinasi akademik, seperti ,regulasi diri, manajemen waktu, dan karakteristik tugas.

\section{Daftar Pustaka}

Ananda, N.y \& Mastuti (2013). Pengaruh Perfeksionisme Terhadap Prokrastinasi Akademik pada siswa program akselarasi. Jurnal Psikologi Pendidikan dan Perkembangan, 2(3)226-231

Andarini, S.R \& Fatma, A (2013).Hubungan Antara Distress dan Dukungan Sosial Dengan Prokrastinasi Akademik Mahasiswa Dalam Menyusun Skripsi. Talenta Psikologi, Vol.II, No.2.,159-179.

Benishek \& Lopez. (2001). Development And Evaluation Of The Revised Academic Hardiness Scale. Journal Of Career Assessment. 9(4), 333-352.

Benishek, L.A, Feldman, J.M, Shipon, R.W, Mecham, S.D \& Lopez, F.G (2005). Development And Evaluation Of The Revised Academic Hardiness Scale. Journal Of Career Assessment, 13 (1), $59-76$

Burka, J.B \& Yuen, L.M. (2008). "Procrastination":Why You Do it, What to Do About it .Cambridge: Da Co Press

Creed, P. A., Conlon, E. G., \& Dhaliwal, K. (2013). Revisiting The Academic Hardiness Scale: Revision And Revalidation. Journal Of Career Assessment, 21, 537-554.

Dweck \& Legget (1988). A Social-Cognitive Approach To Motivation And Personality. Psychological Review. 95,(.2), 256-27.

Etemadi, H \& Feily, A (2016). Prediction of Academic Procrastination among student. Journal Of Academic studies in education and Psychology, I (1), $39-50$

Endrianto, C (2014). Hubungan Antara Self Control dan Prakrastinasi Akademik berdasarkan TMT. Calyptra: Jurnal Ilmiah Mahasiswa Universitas Surabaya, 3 (1), 1-11.

Ferrari, J.R. (1991). Self Handicaping by Procrastination: Perfecting Self Esteem, Sosial Esteem or Both?, 
Journal of Research in Personality, 25(3),245-261

Ferrari. J.R, Johnson, J.I, \& McCowen, W.(1995). Procrastination and task Advoidance, Theory, Research and Treathment. New York: Plenum Press.

Gunawinata,V.A.R, Nanik \& Lasmono, H.K (2008). Perfeksionisme, Prokrastinasi Akademik, dan Penyelesaian Skripsi Mahasiswa. Anima, Indonesian Psychology Journal; vol 23, No.3, 256-276.

Hystad, S.W (2012). Exploring Gender Equivalence And Bias In A Measure Of Psychological Hardiness. International Journal Of Psychological Studies; 4, (4).69-79.

Julianda, B.N. (2012). Prokrastinasi dan Self Efficacy Pada Mahasiswa Fakultas Psikologi Universitas Surabaya. Calyptra 1 No 1, 1-15. dari www. journal.obaya.ac.id/index.php/jime/us/ article/view90. diakses tanggal 11 April 2017.

Kardum I, Knežević, \& Krapić, (2012). The Structure Of Hardiness, Its Measurement Invariance Across Gender And Relationships With Personality Traits And Mental Health Outcomes. Department Of Psychology,

Faculty Of Humanities And Social Sciences, University Of Rijeka, Croatia, 3, 487-507.

Kartadinata, I \& Tjundjing, S. (2008). I Love You Tomorrow: Prokrastinasi Akademik dan Manajemen Waktu. Anima, Indonesian Psychological Journal, 23(2) 109-119.

Maddi, S. R \& Richard, H. H. (2006). The Personality Construct Of Hardiness, III: Relationships With Repression, Innovativeness, Authoritarianism, And Performance. Journal Of Personality 74.2), 575-598.

Maddi, S. R (2006). Hardiness: The Courage To Grow From Stresses. The Journal Of Positive Psychology, 1 (3): 160168.

Nasab,N.F \& Aria, A.M (2015). The Predictive Role Of Religious Beliefs And
Psychological Hardiness In Academic Procrastination Of High School Students (Dalgan). International Research Journal Of Applied And Basic Sciences Available Online At www.Irjabs. Vol, 9 (7), 1082-1087.

Nazmiye \& Asim (2015). Social Comparison

Orientation, Hardiness And Life Satisfaction In Undergraduate Students. A Department Of Counseling And Guidance, Faculty Of Education, Pamukkale University, Denizli, Turkey.

Nurtjahjanti, H \& Ratnaningsih, I.Z. (2011). Hubungan Kepribadian Hardiness Dengan Optimisme pada Calon Tenaga Kerja Indonesia (CTKI) Wanita di BLKLN Disnakertrans Jawa Tengah. Jurnal Psikologi Undip. Vol.10, No.2,126-132

Nela R.U, Ide B. S, \& Nadia S (2013). Prokrastinasi Akademik dan SelfControl pada Mahasiswa Skripsi Fakultas Psikologi Universitas Surabaya.Makara Seri Sosial Humaniora, 17(1): 1-18

Rumiani. (2006). Prokrastinasi Akademik Ditinjau Dari Motivasi Berprestasi Dan Stres Mahasiswa. Jurnal Psikologi Universitas Diponegoro Vol. 3

No. 2., 37-48.

Senecal, C \& Koestner, R. (1995). SelfRegulation And Academic Procrastination. The Journal Of Social Psychology. 135 (5), 607-619.

Sholomon \& Rhothblum. (1984). Academic Procrastination: Frequency And Cognitive-Behavioral Correlates. Jurnal Of Counseling Psychology.31 (4), 503-509.

Steel, P (2007). The Nature Of Procrastination: A Meta-Analytic And Theoritical Review Of Queintessential Self-Regulatory Failure. Physchology Bulletin, 133(1), 65-94.

Sugiyono.(2013). Statistika Untuk Penelitian. Bandung: Alfabeta.

Ursia, N.R, Saputra, I.B \& Sutanto, N (2013).

Prokrastinasi Akademik, dan self control pada Mahasiswa, Makara seri 
Sosial Humaniora, 17(1)1-18.

Vinothkumar, M., Kousalya, \& Rar, V.V (2016). Moderating Roles of Hardiness and Self-Efficacyin the Relationship between Flow and Academic Procrastination onAcademic
Performance: A Structural Equation Model Approach. The International Journal of Indian Psychology. Dari www.ijip.in/index.php.diterima tanggal januari 2017. 